\title{
New Media Access and Use for Triggering the Farmers Capability Improvement in Central Java Indonesia
}

\author{
Shinta Prastyanti ${ }^{1,2}$, Subejo $^{1} \&$ Muhammad Sulhan ${ }^{3}$ \\ ${ }^{1}$ Extension and Development Communication, School of Postgraduate Studies, University of Gadjah Mada, \\ Indonesia \\ ${ }^{2}$ Dept. of Communication Science, University of Jenderal Soedirman, Indonesia \\ ${ }^{3}$ Dept. of Communication Science, University of Gadjah Mada, Indonesia \\ Correspondence: Subejo, Extension and Development Communication, School of Postgraduate Studies, \\ University of Gadjah Mada, Indonesia. E-mail: subejo@ugm.ac.id
}

Received: December 19, 2019; Accepted: January 6, 2020; Published: January 8, 2020

\begin{abstract}
The coconut sugar industry is a hereditary business in Banyumas. However, the low income of farmers, poor education, regeneration, and limited number of extension staffs, are some of the problems associated with its development in rural areas. Therefore an alternative strategy is needed to solve these problems to stay above the competitive and fast-growing market. This study, therefore, aims to determine the access and use of the new media to trigger farmers capability improvement. In-depth interviews and FGD were used to collect data from coconut sugar farmers, extension and cooperative staff, informal leaders, and government officers. Finding show that farmers have the freedom to access new media, though the access is varied based on socio-demographic characteristics. Following their experience in online activity, farmers conduct a social interaction with related parties to discuss the information obtained. Therefore, through this interactive process, farmers tend to realize their functions to improve their capability by obtaining new information, expanding their economic opportunity, affiliation, besides play and emotion.
\end{abstract}

Keywords: new model, coconut sugar farmers, new media, social interaction

\section{Introduction}

Banyumas Regency is one of the centers of coconut sugar production, not only in the province but also on a national scale. The local government along with other related parties have launched programs for the farmers to facilitate and broaden the access to various social-economic opportunities such as The National Program of Rural Mandiri, Kartu Banyumas Pintar (Banyumas Smart Card), Kartu Banyumas Sehat (Banyumas Health Card), and Jambanisasi (Sanitation). According to TNP2K (Tim Nasional Percepatan Pengentasan Kemiskinan), the best strategy for enhancing human capability is empowering poor people groups by creating inclusive development, social protection program, and essential service access improvement (TNP2K, 2017). There is a debate regarding the success of such an initiative, and many feel that the most destitute and needy are often excluded from the program (Hickey \& Sam, 2005).

Banyumas has the potential to develop micro and medium enterprises, such as the rural coconut sugar industry. This is the most important economic activity in the region, and the majority of small and medium enterprises are related to coconut sugar. Unfortunately, most farmers have a basic level of education, and therefore they earn less than the minimum wage. One factor contributing to this issue is the fact that they often rent the trees from wealthier landowners or share them with other farmers (Priyanto, 2010)). Rural coconut sugar enterprises in the Banyumas is a hereditary business. It is dependent on the weather, and therefore the income received by farmers is also uncertain, similar to the fluctuated amount of production and the price of coconut sugar. Also, climbing coconut trees is a risky job since the farmers have to reach a height of twenty-five meters without a safety belt, while the coconut sugar trees need to be harvested throughout the year (Singarimbun and Penny, 1976).

Farmers need to be able to increase the quantity and quality of their products to meet market demand. However, the extension programs carried out by the government and related parties to improve their capability, have not been able to reach all coconut sugar farmers due to the limited number of unparalleled extension staff. This study 
is, therefore, important due to the new media access and its use as an alternative solution to improving farmers' capability.

The implementation of some innovative and potential strategies which focus on strengthening human capability is a practical approach in this regard. This involves people's participation in supporting daily economic activities and solving social problems through the utilization of information and communication technology. According to Manovich (2001), new media are interactive, incorporates two-way communication, and involve some form of computing. They are highly interactive, and the users are active producers of content and information using internet collaboration tools or sending an email. With these characteristics, new media has great potential to attract people's interest in case it is used as a tool to enhance their capabilities (Shilpa 2014).

\section{Literature Review}

Capability is not just about something that can be done or achieved by a person or a group. It involves the freedom to promote valuable functioning (Nusbaumm, 1993; Saith, 2001; Alkire, 2002). Further, Sen (1999) argued that capability is the alternative combinations of functions that are feasible to achieve. Generally, improving human capability involves all efforts to improve or develop individual characteristics to make them more effective and efficient (Mardikanto, 2010). It includes a genuine choice with substantial options and needs the expansion of goods and services (Sen, 1983).

The new media characteristic makes it possible for the farmers to access and to use any information relevant to improve their human potential. According to some studies, new media tools such as mobile phones and the internet have a significant role in reducing poverty and improving rural livelihoods. This is because they expand and strengthen social networks and economic activities, maximize outcome, and increase accessibility (Grimes, 1992; Grimes, 2000; Mercer, 2006; Galperin \& Mariscal, 2007; Galperin et al., 2014). Also, there is evidence that ICTs assist in poverty reduction and expand opportunities for economic development (Duncombe \& Heeks, 2002; Prosser, 2000). Furthermore, Ellis (2000) argued that access to information provides an opportunity for undertakes production, participate in reciprocal exchanges with other people, and engage in the labor market. Quibra et al. (2002) stated that information and communication technology could be one of the essential sources of market information. The position of ICT as a source of market information gives it a significant contribution to improving human capability (Silverstone, 1999). The capability to survive, be healthy, and knowledgeable, and enjoy a decent life is considered to be the strategy for human development (Fukuda-Par, 2003). Some scholars developed theoretical links between ICTs and capabilities (Johnstone, 2007; Gigler, 2004; Kleine \& Unwin, 2010). Their significant findings are expanded possibilities for connectedness between people and increased access to timely and relevant information (Smith et al., 2011). Moreover, Alampay (2006) configured The Capability Approach Applied to Access to ICTs where individual differences with the freedom to express the capability to use ICT.

\section{Method}

This is a descriptive and semi-exploratory research with a qualitative approach. In general, qualitative research aims to explore and understand the meaning of phenomena considered from social and humanitarian problems (Creswell, 2010). The informants of this research were selected by purposive sampling. This includes an in-depth understanding of the research theme, such as government officer, extension and cooperative staffs, and informal leader. The rural coconut sugar farmers were selected informants based on the information obtained from the head of the village and informal leaders. The criteria of informants are the coconut sugar farmers who access and usage of new media.

Primary data is the direct info collected from the research object by in-depth interviews, FGD, and observation. Secondary data is obtained from literature/ library/ documents relevant to the topic of the research, including the government's track record to the support given to the implementation of the new media and human capability improvement. The data were recorded in a tape recorder and analyzed and reinterpreted to suit the research theme and generate new findings (Bakti, 2004). Data examination used an interactive analysis model, which is an interactive and cyclic process (Miles \& Huberman, 2002). Moreover, data validity used source and method triangulation to collect data from different sources for more accuracy (Patton, 1987). For data analysis was used an interactive model which is an interactive and cyclus process (Miles \& Huberman, 2002).

\section{Results and Discussion}

Findings of the study show that the new media was accessed and utilized by the farmers at the research location through three types of information and communication technology, including Personal Computer, notebook, and smartphone. The community owns the PC and placed in the village hall office. Personal Computer is only 
accessible to a small proportion of rural people due to its limited number. The notebook is private property, though not many rural people use it. Compared to a PC, the ownership of the notebook is higher. Unlike PCs and notebook, almost all families have a smartphone, and its use can be different between individuals since it is private property.

Apart from mobile phones, new media cannot be separated from the Internet. Stern \& Adams (2010) established that the Internet plays a significant role in building social capital in rural society. Additionally, Alemna \& Sam (2006), in their research in Ghana, also found the potential of the internet for rural development, especially in agriculture, health, education, and small industries. It enables the development of community-based infrastructure, the small scale investment, and also the uses of experimental results (Galperin, 2005).

In this study, the access and use of new media was seen from the literacy level regarding its usage, the availability of the device, and the dominant activity. Coconut sugar farmers who access and use the internet have enough ability to operate that device. They understand that new media offers many services for different purposes. Through the internet, they find various information needed from Google and Youtube, as well as group accounts they follow, such as Facebook and WhatsApp. Furthermore, they also know that smartphones not only help to look for the required information, connecting them with their relatives and friends. It helps to increase affiliation, economic opportunity for their coconut sugar products, and entertainment. Although not all the information accessed from the internet is directly related to the rural coconut sugar industry, skills are still needed for access.

This research also found that all farmers have not adopted crystal coconut sugar. The reluctance to switch to it is proof that they do not have an open mind even though some of the coconut sugar farmers admit that producing it might be more profitable. Openness to cyberspace was not in line with their willingness to innovate by switching to crystal coconut sugar.

Media literacy does not only involve the ability to access and create messages but also to critically evaluate and analyze its aspects and the message in different contexts (European Commission, 2007). In this research, media literacy was not studied until farmers were able to evaluate various aspects related to new media and its contents. The farmers who still produce shaped coconut sugar form messages that motivate young people to follow their footsteps since there are challenges relating to regeneration. According to Walters et al. (1999) and Perkins et al. (2007), young people face obstacles, including being involved in the rural coconut industry, variations between personal decisions, peer group influences, the level of local knowledge, and community cohesion. At first, some farmers forgot the time for accessing the internet, though with time they could manage and control it. All coconut sugar farmers accessing the internet have a high level of media literacy. However, farmers in medium level do not have sufficient ability to use the internet maximally, for example, to create inspiring messages to promote coconut sugar online. In contrast, some farmers have the ability to use the internet for more productive things related to the coconut sugar industry. Nevertheless, they did not use their ability to access and use new media for enhancing coconut sugar farming and the industry in general. According to Fianagin \& Metzger (2001), conversation, searching, and sending information is the three essential internet functions for individuals, including coconut sugar farmers. Furthermore, James (2006) argued how the internet is significantly affected its benefits. Other aspects influence coconut sugar farmers' capability improvement, such as the device. For instance, without the device, new media activities cannot be accessed by farmers. In every village, there is a website, though coconut sugar farmers do not fully utilize it since people prefer to access the internet through a smartphone, including farmers. The availability of the device for all family members eases communication with others. However, there are coconut sugar farmers who do not have a smartphone but use their cellphones to call and send text messages.

Table 1. New media access and use based on media literacy and the availability of the device

\begin{tabular}{|c|c|c|c|}
\hline $\begin{array}{l}\text { Types of coconut } \\
\text { sugar farmer }\end{array}$ & $\begin{array}{l}\text { The availability of } \\
\text { the device }\end{array}$ & $\begin{array}{l}\text { The types of the } \\
\text { device }\end{array}$ & $\begin{array}{l}\text { Level of literation } \\
\text { to new media }\end{array}$ \\
\hline $\begin{array}{l}\text { Shaped coconut sugar with no internet } \\
\text { access }\end{array}$ & Available & cellphone & Low \\
\hline $\begin{array}{l}\text { Shaped coconut sugar } \\
\text { with internet access }\end{array}$ & Available & $\begin{array}{l}\text { PCs, notebook, } \\
\text { smartphone }\end{array}$ & High \\
\hline $\begin{array}{l}\text { Crystal organic coconut sugar (with internet } \\
\text { access not for promoting the product) }\end{array}$ & Available & smartphone & Medium \\
\hline $\begin{array}{l}\text { Shaped \& crystal coconut sugar (indirect } \\
\text { access on the internet) }\end{array}$ & Not available & - & Low \\
\hline Shaped \& crystal coconut sugar (with & & & High \\
\hline
\end{tabular}




\begin{tabular}{llll}
\hline internet access not for promoting the Available & smartphone & \\
product) & & \\
$\begin{array}{l}\text { Shaped \& crystal coconut sugar (with } \\
\text { internet access for promoting the product) }\end{array}$ & Available & smartphone & \\
\hline
\end{tabular}

Source: Researcher (2019)

\subsection{Dominant Activity}

There was similarity in dominant activity among coconut sugar farmers, including social media, transactions, and searching for information. Social media activities are used primarily to connect with family and friends through their accounts, with WhatsApp and Facebook as the most preferred platforms. According to the informants, these two social media applications are easy to operate, and most of their friends and relatives also use them. Twitter, Instagram, and other types of social media applications are not preferred or accessed by coconut sugar farmers. According to Mascarenhas (2010), the most crucial advantage of the mobile phone includes facilitating the ability to communicate and be connected to others, maintaining family and social relations, vital in an emergency, and essential for other daily activities. This research established that transactions are also integral part of the life of coconut sugar farmers in Banyumas. Leasing trees, mortgages, and lending money are often coordinated through social media platforms such as WhatsApp. Coconut sugar farmers do not have to spend time meeting on the face with their colleagues, apart from enjoying other economic benefits of mobile phones (Aker \& Mbiti, 2010; Rangaswamy \& Nair, 2010). Coconut sugar farmers also follow the events in the region, something that cannot be ignored. According to farmers, it is essential to follow many events that happen in the surrounding. The information related to the region is accessed through Google and WhatsApp group, such as events carried out by the local government, accidents, and disasters, which affects the coconut sugar price. All farmers have direct internet access through smartphones, except a farmer who uses a personal computer (PC) and notebook. However, farmers did not use the village website because of the accessibility of other platforms, such as smartphones that can be taken everywhere. Smith et al. (2011) argue that capabilities and freedoms in social spheres are substantial contributions to mobile phones.

The coconut sugar farmers who have accessed the internet, as described above, are different from others. The ICT devices accessed are television and cellphone, which can be used to call and send a text message. Following the news broadcast on television, getting entertainment from soap opera, communicating with relatives and family is considered essential. According to Mizuko et al. (2009), old media such as television intersecting with new interactive devices are vital (Williams et al. (1994). The 4th type of farmers produce shaped, and crystal coconut sugar farmers and have indirect internet access.

Table 2. New media dominant activity of coconut sugar farmer

\begin{tabular}{|c|c|c|c|c|c|}
\hline $\begin{array}{l}\text { Types of coconut } \\
\text { sugar farmer }\end{array}$ & $\begin{array}{l}\text { Dominant } \\
\text { activities of } \\
\text { new media } \\
\text { usage }\end{array}$ & $\begin{array}{l}\text { Urgency/ need } \\
\text { for communi- } \\
\text { cation }\end{array}$ & $\begin{array}{l}\text { Types of new } \\
\text { media }\end{array}$ & $\begin{array}{l}\text { Types of } \\
\text { applica- } \\
\text { tion of new } \\
\text { media } \\
\end{array}$ & Characteristics \\
\hline $\begin{array}{l}\text { Shaped coconut } \\
\text { sugar with no } \\
\text { internet }\end{array}$ & $\begin{array}{l}\text { Phone, send a } \\
\text { text message, } \\
\text { watching TV }\end{array}$ & $\begin{array}{l}\text { Communicate } \\
\text { with relatives } \\
\text { and family, } \\
\text { transaction, } \\
\text { entertainment, } \\
\text { getting } \\
\text { information }\end{array}$ & - & - & $\begin{array}{l}\text { Quick respond, } \\
\text { entertain }\end{array}$ \\
\hline $\begin{array}{ll}\text { Shaped } & \text { coconut } \\
\text { sugar } & \\
\text { with } & \text { internet } \\
\text { access } & \end{array}$ & $\begin{array}{l}\text { Social media, } \\
\text { email, } \\
\text { googling }\end{array}$ & $\begin{array}{l}\text { Communicate } \\
\text { with relatives } \\
\text { and family, } \\
\text { finding } \\
\text { information, } \\
\text { support work, } \\
\text { transaction }\end{array}$ & $\begin{array}{l}\text { Personal } \\
\text { computer } \\
\text { (PC), } \\
\text { notebook, } \\
\text { smart-phone }\end{array}$ & $\begin{array}{l}\text { Google, } \\
\text { Yahoo, } \\
\text { Facebook, } \\
\text { WhatsApp, } \\
\text { Email }\end{array}$ & $\begin{array}{l}\text { Quick respond, } \\
\text { high flexibility } \\
\text { focus, similarity } \\
\text { interest, deliver } \\
\text { detail information, } \\
\text { offer complete } \\
\text { information }\end{array}$ \\
\hline $\begin{array}{l}\text { Crystal organic } \\
\text { coconut } \\
\text { sugar }\end{array}$ & Social media & $\begin{array}{l}\text { Communicate } \\
\text { with relatives }\end{array}$ & Smart-phone & $\begin{array}{l}\text { WhatsApp, } \\
\text { Google }\end{array}$ & $\begin{array}{l}\text { Quick respond, } \\
\text { high }\end{array}$ \\
\hline
\end{tabular}




\begin{tabular}{|c|c|c|c|c|c|}
\hline $\begin{array}{l}\text { (with internet } \\
\text { access not for } \\
\text { promoting the } \\
\text { product) }\end{array}$ & & $\begin{array}{l}\text { and family, } \\
\text { finding } \\
\text { information, } \\
\text { transactions }\end{array}$ & & & $\begin{array}{lr}\text { focus, } & \text { similarity } \\
\text { interest, } & \text { offer } \\
\text { complete } \\
\text { information }\end{array}$ \\
\hline $\begin{array}{l}\text { Shaped \& crystal } \\
\text { coconut sugar } \\
\text { (indirect access } \\
\text { on the internet) }\end{array}$ & $\begin{array}{l}\text { Attending the } \\
\text { Cooperative of } \\
\text { Nira Satria } \\
\text { meeting }\end{array}$ & $\begin{array}{l}\text { Finding } \\
\text { information, } \\
\text { experience }\end{array}$ & - & - & $\begin{array}{l}\text { Delay respond, } \\
\text { depending on other } \\
\text { people }\end{array}$ \\
\hline $\begin{array}{l}\text { Shaped \& crystal } \\
\text { coconut sugar } \\
\text { (with internet } \\
\text { access not for } \\
\text { promoting the } \\
\text { product) }\end{array}$ & $\begin{array}{l}\text { Social media, } \\
\text { download } \\
\text { songs }\end{array}$ & $\begin{array}{l}\text { Communicate } \\
\text { with relatives } \\
\text { and family, } \\
\text { finding } \\
\text { information, } \\
\text { transaction }\end{array}$ & Smart-phone & $\begin{array}{l}\text { Facebook, } \\
\text { WhatsApp, } \\
\text { Google, } \\
\text { Youtube }\end{array}$ & $\begin{array}{l}\text { Quick response, } \\
\text { high flexibility } \\
\text { focus, similarity } \\
\text { interest, offer } \\
\text { complete } \\
\text { information, } \\
\text { entertain }\end{array}$ \\
\hline $\begin{array}{l}\text { Shaped \& crystal } \\
\text { coconut sugar } \\
\text { (with internet } \\
\text { access for } \\
\text { promoting the } \\
\text { product) }\end{array}$ & $\begin{array}{l}\text { Social media, } \\
\text { promotion }\end{array}$ & $\begin{array}{l}\text { Communicate } \\
\text { with relatives } \\
\text { and family, } \\
\text { transaction }\end{array}$ & Smart-phone & $\begin{array}{l}\text { WhatsApp, } \\
\text { Facebook }\end{array}$ & $\begin{array}{ll}\text { Quick } & \text { respond, } \\
\text { high } & \text { flexibility } \\
\text { focus, similarity } & \text { interest, entertain }\end{array}$ \\
\hline
\end{tabular}

Source: Researcher (2019)

\subsection{Social Interaction after Getting Information from New Media}

The information obtained by the farmers from the internet is shared and discussed among community members through social interaction. Every member of the community has their perspectives, and it should be understood, mobilized, and organized. Communication creates relationships among stakeholders or between beneficiaries through the messages delivered (Prastyanti, 2012). The target audience understands the meaning of the message in case it is delivered with sarity, appropriately, and novelty (Mulyana, 2000). Social interaction creates a secure network that allows the community members to manage and improve control over their resources. A network formed foster healthy relationships, trust, and togetherness, and develop joint actions among members of the community network itself (Torri, 2009). The behavior of each society member also creates a synergy that has strong connectivity with solidarity (Littlejohn, 2001). The essence of solidarity, according to Amsperger \& Varoufakis (2003), is based on the hypothesis that people give a sympathetic opinion on conditions faced by others.

Social interaction in the communities contributes to people's participation, which has a positive contribution, both individually and collectively. As an individual, it affects the quality of life while collectivity, it fosters a sense of belonging to the surrounding environment (Ohmer, 2007; Itzhaky and York, 2002). A sense of belonging to the surrounding environment is a social capital in the creation of participation, which contributes to sustainable development (Kwiatkowski, 2005; people-centered development). Moreover, it also improves information access, economic opportunities, and growing self-confidence (Soetomo, 2006).

Wellman et al. (2001) state that the internet is not only a means of socializing through various applications such as WhatsApp, email, Facebook, and Instagram, but it also used for other things. However, online interactions do not entirely replace face-to-face communication; it only complements it and serves as an encouragement for farmers in realizing their roles and potential as human beings. Based on The Capability Approach Applied to Access to ICTs developed by Alampay's (2006), the coconut sugar farmers in Banyumas have the freedom to access and use their assets, including new media devices. They are also free to search or choose the needed information. Nevertheless, freedom cannot be separated from the ability and experience to operate it. Richards and Dalbey (2006) stated that before addressing the options, information on a range of possible alternatives is needed by the community members. According to Nussbaum's central human functional capabilities (Nussbaum, 2000), mediation through new media is called affiliation. The expansion of the network unites them and become a valuable social capital. Warschauer (2003) argues that social capital can be enhanced by access to ICT. However, interaction with outsiders also contributes to the motivation of farmers to obtain further information that energizes and mobilizes them. According to the Expectancy theory developed by Vroom (1964), people can be motivated 
when they believe there is a high value of the reward. In case farmers can motivate each other and get rewards, social interaction repeatedly occurs beyond the limits of space and time.

That above process is also relevant to The Element of Social Interaction by Turner (1988), which states that coconut sugar farmers who interact both offline and online influence each other and are organized in social interaction. In the process, they use symbols that involve the part of the body to send or translate messages received to provide mutual motivation. The process of social interaction provides more significant space for coconut sugar farmers to realize their functions, which is triggering the improvement of their capabilities. Expanding freedom enjoyed by farmers follows the concept of The Capability Approach developed by Sen (1999). According to this approach, human capability improvement is not focused on the economic aspect. In this context, increasing the farmer's potential through new media access and use does not necessarily mean an increase of income, but instead expanding network that allows broadening of the market through online channels, besides improving knowlwdge by getting new information such as coconut tree genjah entok seedlings and gluteen. Similarly, Shirin (2000) argued that denied access to new media does not necessarily influence economic activities.

The process of triggering coconut sugar farmers' potential improvement in this study can be analyzed by Nussbaum's central human functional capabilities (Nussbaum, 2000). Emotions are one of the significant indicators of human functional capabilities. In this regard, farmers empathize with each other, for example, when a farmer fell from a coconut tree couple of years ago, the information immediately spread through the WhatsApp groups. The new media also relieve farmers from stress due to their routine jobs by getting entertained by the content they access from the new media. A young coconut sugar farmer stated that:

"Yes, I gained access to the internet two years ago and it has been entertaining. I spend about two hours a day on WhatsApp, Facebook, and Youtube downloading songs. The internet is important to me because I feel happy after conducting an online activity and it helps me to forget my routine job for a while".

In the beginning, some farmers tend to forget the time they accessed the Internet. They spend lots of hours and most times fail to realize that they need to climb the coconut trees again. However, they are currently able to manage and control the Internet use, as stated by another coconut sugar farmer:

"At first, the Internet made me forget to work. I failed to realize that I was spending so much time on my gadget, while I have to climb the coconut tree. However, the reverse is the case now, as I only make use of it whenever I need to acquire some information. The Internet is entertaining and makes me happy anyway".

However, this study tries to determine new media access and use for triggering farmers capability improvement by modifying its findings using The Capability Approach Applied to Access on ICTs by Alampay (2006) and central human functional capabilities delivered by Nussbaum (2000) as shown in the figure below.

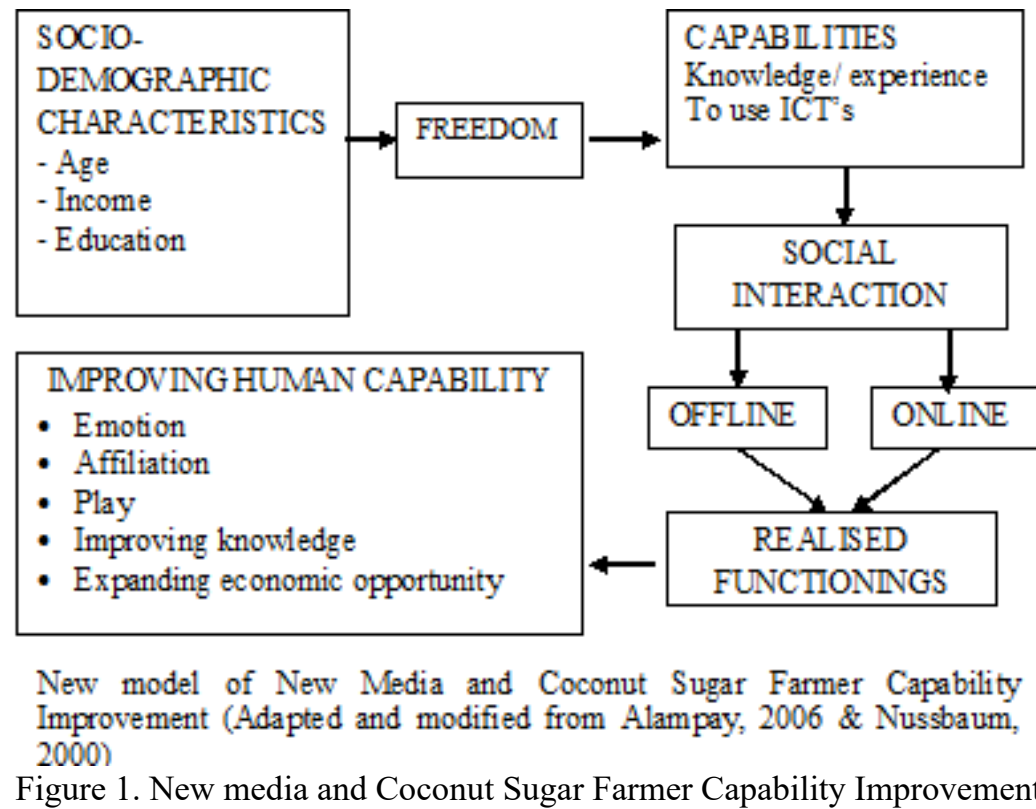

Source: Researcher (2019) 


\section{Conclusion}

In conclusion, literacy to new media, the availability of technological devices, and dominant activity are the factors used to analysis new media access and use of coconut sugar farmers to trigger their capabilities improvement. Currently, most farmers do not face any obstacle in accessing the internet and understand that the new media offers many services for many purposes. The use of these media provides them with various required information through smartphone, PC, or notebook. In addition, the dominant activities that are carried out are social media interactions, transactions, and the search for information related to events around Banyumas. Google, Youtube, and group accounts such as Facebook and WhatsApp, are their favorite applications, with Emails used to send files.

The access and use of the new media to trigger human capability aids to improve the activities of the coconut sugar farmers in Banyumas. The farmers need the ability and experience to operate the device. However, the information received from the new media does not directly improve the capabilities of the farmers, rather the social interaction carried out with related parties mutually motivate and foster empathy among them with a complete and clearer ideology. This makes farmers happy, entertained, and they tend to briefly forget their daily routines.

The efforts to develop the rural coconut sugar industry by increasing the capabilities of the farmers are unable to function optimally without the participation of the government in making policies. To solve the limited number of extension staffs, the new media functions as an empowerment alternative model for farmers capability improvement while paying attention to their different characteristics. In addition, the quality of the internet network needs to be improved to make it easier for farmers to gain access besides the village website needs to be reactivated because it is one of the important media for outsiders to determine its resources which includes the coconut sugar industry.

For further research, the role of women and the importance of the contribution of the cooperative in the development of the rural coconut sugar industry need to be studied. Furthermore, the new media has not been accessed and used by all farmers, therefore research on how the process of coconut sugar farmers in adopting thenew media to support their hereditary business is also important.

\section{References}

Aker, J. C., \& Mbiti, I. M. (2010). Mobile Phones and Economic Development in Africa. Journal of Economic Perspectives, 24(3), 207-232. https://doi.org/10.1257/jep.24.3.207

Alampay, E. A. (2006). Beyond access to ICTs: Measuring capabilities in the information society. International Journal of Education and Development using ICT, 2(3), 1-21.

Alemna, A. A., \& Sam, J. (2006). Critical Issues in Information and Communication Technologies for Rural Development in Ghana. Journal Information Development, 22(4), 236-241. https://doi.org/10.1177/0266666906074181

Alkire, S. (2002). Dimensions of Human Development. World Development, 32(2), 181-205. https://doi.org/10.1016/S0305-750X(01)00109-7

Arnsperger, C., \& Varoufakis, Y. (2003). Toward a Theory of Solidarity. Erkenntnis, 59(2), 157-188. https://doi.org/10.1023/A:1024630228818

Bakti, A. F. (2004). Communication and Family Planning in Islam in Indonesia. South Sulawesi Muslim Perceptions of a Global Development Program. Jakarta-Leiden: INIS.

Creswell, J. W. (2010). Research Design. Pendekatan Kualitatif, Kuantitatif, dan Mixed. Edisi Ketiga. Yogyakarta: Pustaka Pelajar.

Duncombe, R. A., \& Heeks, R. B. (2002). "Enterprise Across the Digital Divide: Information System and Microenterprise in Botswana. Journal of International Development, 14(1), 61-74. https://doi.org/10.1002/jid.869

Ellis, F. (2000). Rural Livelihoods and Diversity in Developing Countries, Oxford: Oxford University Press.

European Commission. (2007) in Koltay, T. (2011). The media and the literacies: Media literacy, information literacy, digital literacy. Media Culture Society, 33(2), 211-221. https://doi.org/10.1177/0163443710393382

Fianagin, A. J., \& Metzger, M. J. (2001). Internet use in the contemporary media environment. Human Communicastion Research, 27(1), 153-181. https://doi.org/10.1093/hcr/27.1.153

Fukuda-Par, Sakiko. (2003). The Human Development Paradigm: OperationalizingSen's Ideas on Capabilities. Feminist Economics, 9(2-3), 301-317. https://doi.org/10.1080/1354570022000077980

Galperin, H. (2005). Wireless Networks and Rural Development: Opportunities for Latin America. Information 
Technologies and International Development, 2(3), 47-56. https://doi.org/10.1162/1544752054782420

Galperin, H., \& Mariscal, J. (2007). Mobile Opportunities: Poverty and Mobile Telephony in Latin America and the Caribbean, DARSI (Dialogo Regional Sobre Sociedad de la Informacion).

Galperin, H., Mariscal, J., Barrantes, R. (2014). Internet and poverty: Opening the black box. IDRC Digital Library.

Gigler, B. (2004). Can ICTs empower poor communities? Towards an alternative evaluation framework based on the capability approach.Presented at the Fourth International Conference on the Capability Approach, Pavia, Italy.

Grimes, S. (1992). Exploiting information and communication technologies for rural development. Journal of Rural Studies, 8(3), 269-278. https://doi.org/10.1016/0743-0167(92)90004-P

Grimes, S. (2000). Rural areas in the information society: diminishing distance or increasing learning capacity? Journal of Rural Studies, 16(1), 13-21. https://doi.org/10.1016/S0743-0167(99)00027-3

Hickey, S., \& Sarah, B. (2005). Exploring the Politics of Chronic Poverty: From Representation to a Politics of Justice? World Development, 33(6), 851-865. https://doi.org/10.1016/j.worlddev.2004.09.012

Johnstone, J. (2007). Technology as empowerment: A capability approach to computer ethics. Ethics and Information Technology, 9(1), 73-87. https://doi.org/10.1007/s10676-006-9127-x

Kleine, D., \& Unwin, T. (2009). Technological Revolution, Evolution, and New Dependencies: what's new about ict4d? Third World Quartely, 30(5), 1045-1067. https://doi.org/10.1080/01436590902959339

Kwiatkowski, L. (2005). NGOs, Power and Contradiction in Ifugao, the Philippines, Urban Anthropology \& Studies of Cultural Systems \& World Economic Development, 34(4), 385-436.

Littlejohn, W. S. (2002). Theories of Human Communication. Wadsworth.

Manovich, Lev. (2001). The Language of New Media. Cambridge, Mass.: The MIT Press.

Mardikanto, T. (2010). Komunikasi Pembangunan. Acuan bagi Akademisi, Praktisi, dan Peminat Komunikasi Pembangunan. Solo: Sebelas Maret University Press

Mascarenhas, O. (2010). Broadening the Agenda for ICTs for Poverty Reduction: PICTURE-Africa. Information Technologies \& International Development, 6(SE), 37-44.

Miles, \& Huberman. (2002). The Qualitative Research's Companian. Sage Publishing. India. https://doi.org/10.4135/9781412986274

Mizuko, I., Heather, H., Matteo, B., Danah, B., Becky, Stephenson, H., ... Lisa, T. (2009). Living and Learning with New Media: Summary of Findings from the Digital. Cambridge, Massachuset: The MIT Press.

Mulyana, D. (2000). Ilmu Komunikasi, Suatu Pengantar. Bandung: PT Remaja Rosdakarya.

Nussbaum, M. C. (1993). Non-Relative Virtues: An Aristotelian Approach. In M. Nussbaum and A. Sen (eds) The Quality of Life, 242-269. https://doi.org/10.1093/0198287976.003.0019

Nussbaum, M. C. (2000). Women and human development: The capabilities approach. Cambridge: Cambridge University Press. https://doi.org/10.1017/CBO9780511841286

Ohmer, M. L. (2007). Citizen Participation in Neighborhood Organizations and Its Relationship to Volunteers' Self- and Collective Efficacy and Sense of Community, Social Work Research, 31(2), 109-120. https://doi.org/10.1093/swr/31.2.109

Patton, M. Q. (1987). How to use qualitative methods in evaluation. Newbury Park, CA: Sage.

Perkins, D. F., Borden, L. M., Villarruel, F. A., Carlton-Hug, A., Stone, M. R., \& Keith, J. G. (2007). Participation in structured youth programs: Why ethnic minority urban youth choose to participate — or not to participate. Youth \& Society, 38(4), 420-442. https://doi.org/10.1177/0044118X06295051

Prastyanti, S. (2012). Mengkomunikasikan Pembangunan Pada Masyarakat Pedesaan. Acta Diurna, 8(1), 10-15.

Priyanto, D. (2010). Majalah Ilmiah Ekonomika, 13(4), 130-162.

Prosser, T. (2000). The Law and Regulators, Oxford: Clarendon Press.

Quibria, M. G., Tschang, T., \& Macasaquit, M. L. R. (2002). New Information and Communication Technologies and Poverty: Some evidence from developing countries. Journal of the Asia Pacific Economy, 7(3), 285-309. https://doi.org/10.1080/1354786022000007852

Rangaswamy, N., \& Nair, S. (2010). The Mobile Phone Store Ecology in a Mumbai Slum Community: Hybrid 
Networks for Enterprise. Information Technologies and International Development, 6(3), 51-65.

Richards, L., \& Dalbey, M. (2006). Creating great places: The role of citizen participation. Journal Community Development, 37(4), 18-32. https://doi.org/10.1080/15575330609490193

Saith, R. (2001). Capabilities: The Concept and its Operationalisation. QEH Working Paper Series, 66, Queen Elizabeth House, University of Oxford.

Sen, A. K. (1983). Development: Which Way Now? Economic Journal, 93(37), 745-762. https://doi.org/10.2307/2232744

Sen, A. K. (1999). Development as Freedom, New York: Knopf Press.

Shilpa, J. (2014). A New Media Technology In Education: A Genre of Outreach Learning. Global Media JournalIndian, 5(1), 1-10.

Shirin, M. (2000). The Internet and socio-economic development: Exploring the interaction. Information Technology \& People, 13(2), 85-101. https://doi.org/10.1108/09593840010339835

Silverstone, R. (1999). What's new about new media?. New media and society, 1(1), 10-82. https://doi.org/10.1177/1461444899001001002

Singarimbun, M., \& Penny, D. H. (1976). Penduduk dan kemiskinan; Kasus Sriharjo di Pedesaan Jawa, Jakarta: Bharata Karya Aksara.

Smith, M. L., Randy, S., \& Rashid, A. T. (2011). Mobile Phones and Expanding Human Capabilities. Journal of Information Technologies and International Development, 7(3), 77-88.

Soetomo. (2006). Strategi-Strategi Pembangunan Masyarakat, Yogyakarta: Pustaka Pelajar.

Stern, M. J., \& Adams, A. E. (2010). Do Rural Residents Really Use the Internet to Build Social Capital? An Empirical Investigation. American Behavioral Scientist, 53(9), 1389-1422. https://doi.org/10.1177/0002764210361692

Torri, M. C. (2009). Enhancing learning and innovation among local Communities through networks in poor rural areas: The case study of GMCL, India. International Journal of Rural Studies (IJRS), 16(1), 1-13.

Tuner, J. H. (1988). A Theory of Social Interaction. Clifornia: Stanford University Press, 11(1). Retrieved from http://www.irrodl.org/index.php/irrodl/article/view/794/1487

Vroom, V. (1964). Work and motivation. New York: Wiley.

Walters, B. B., Cadelina, A., Cardano, A., \& Visitacion, E. (1999). Community history and rural development: Why some farmers participate more readily than others. Agricultural Systems, 59(2), 193-214. https://doi.org/10.1016/S0308-521X(99)00003-7

Warschauer, M. (2003). Dissecting the "Digital Divide": A Case Study in Egypt. The Information Society, 19, $297-$ 304. https://doi.org/10.1080/01972240309490

Wellman, B., Annabel, Q., \& Witte, J. (2001). Does the Internet Increase, Decrease, or Supplement Social Capital? Social Networks, Participation, and Community Commitment. American Behavioral Scientist, 45(3), 439455. https://doi.org/10.1177/00027640121957286

Williams, F., Strover, S., \& Grant, A. E. (1994). Social aspects of new media technologies. In J. Bryant and D. Zillman (eds). Media effects: Advances in theory and research, Hillsdale, NJ: Erlbaum, 463-482.

\section{Copyrights}

Copyright for this article is retained by the author(s), with first publication rights granted to the journal.

This is an open-access article distributed under the terms and conditions of the Creative Commons Attribution license (http://creativecommons.org/licenses/by/4.0/). 